\title{
Digitization of Taxation in the Changing Business Environment \& Base Erosion \& Profit Shifting (Beps) Special Reference to India
}

\author{
Shireen Rosario, Lecturer \\ Dr. Kavita Chavali, Associate Professor \\ Department of Accounting and Finance \\ College of Commerce and Business Administration \\ Dhofar University, Sultanate of Oman
}

URL:http://dx.doi.org/10.19044/esj.2020.v16n1p61

\begin{abstract}
The ever-increasing digitization of businesses around the world is forcing tax authorities to re-look at the way they regulate compliance of tax rules by the tax payers and collect more efficiently taxes that are due. Most of the tax laws were framed in the $20^{\text {th }}$ century and may no longer be relevant in the digitized world of the $21^{\text {st }}$ century. This paper looks at the need for enhanced methods of tax administration and collection in view of the digitization of businesses, the threat of Base Erosion and Profit Shifting (BEPS) and the need for rapid digitization of tax administration. The paper also focuses on the role played by the Organization for Economic Cooperation and Development (OECD) and the advancement in tax administration achieved by various countries with special reference to India. It is observed that as many as 115 countries are aggressively moving towards digitization as a result of call by OECD for greater co-operation. India, though not part of the OECD, has implemented many measures, especially bilateral tax treaties with 50 countries and is also earnestly pursuing digitization to improve tax collection.
\end{abstract}

Keywords: Digitization, taxation, compliance, global, tax authorities

\section{Introduction}

Emerging technologies offer a tremendous amount of opportunities to define the way business is carried on, markets are defined, reshape the methods of work, define relationships with customers/clients and with regulatory authorities.

The changing business scenario, high end technologies, globalization, web of tax rules and the dire need for transparency in the system has made 
digitization of taxation a "must have" rather than "good to have" for tax authorities as well as tax payers. As advanced technologies are now available, it is imperative to make changes and avail of the benefits of the digitization to increase competitiveness and also to mitigate risk.

The increased digitization throws two major challenges at governments and tax authorities. Firstly, to be in line with the changing business environment and adapt to the ever-changing digital world of business and secondly, ensure that tax base is widened and income leakages are plugged to obtain the maximum taxes for the development of nations.

\section{Base Erosion and Profit Shifting (BEPS):}

Base Erosion and Profit Shifting or BEPS refers to corporate tax strategies where profits are shifted from high tax jurisdictions to No tax / low tax jurisdictions, thus eroding the base of taxation in high tax jurisdictions. The Organization of Economic Co-operation and Development (OECD) also defines BEPS as "exploiting gaps and mismatches in tax rules". Though prevalent all over the world, BEPS tools are mostly used by US technology and life science multinationals (www.oecd.org). Life science multinationals are multinationals engaged in biotechnology, pharmaceuticals, biomedicals, biopolymers, food science, genomics .....that concern life and organisms such as plants, microorganisms and animals including human beings.

With increased digitization and change in the business methods come the increasing incidences of tax avoidance and hidden wealth around the world both legally and illegally. Cobham \& Jansky (2015) find three main aspects in their research on tax avoidance. First, base erosion and profit Shifting is a huge problem and would rank among the first in terms of world economy. An estimated US $\$ 660$ billion of corporate profits were shifted in 2012, that would have been equal to more than $25 \%$ of US multinational gross margins or equal to $0.9 \%$ of the world GDP. Second, countries of all income levels are losing out to profit shifting and most of the "missing" profits end up in a few tax jurisdictions with near to zero effective tax rates. Finally, in the United States the profit shifting has grown alarmingly as compared to the latter part of the $20^{\text {th }}$ century. While in the late 1990 s this figure stood around $5-10 \%$ of the total profits, in the last two decades it has increased to $25-30 \%$ of the total profits. It is also noted by authors that profit shifting is despite lowering of tax rates by countries, which is counter intuitive. It is expected that when a country tries to lower tax rates and work like a tax haven, it is expected that profits would not leave the country. However, the opposite has been happening. This is an extremely important finding because in the race to lower tax rates, governments have only lost out on tax revenues.

BEPS has also been a huge problem in developing countries, Especially in Asia and Africa. Revenue that would otherwise been helpful in 
nation building, is taking a flight from the country. A joint report in 2013 by African Development Bank and Global Financial Integrity reported that after adjusting all the recorded financial flows to and from the African continent, Africa would have been the net creditor to the rest of the world by around US\$ 1.4 trillion. (African Development Bank and Global Financial Integrity 2013: 2). According to Global Financial Integrity, illicit financial flows from South Africa alone were to the tune of $\$ 122$ billion between 2003 and 2012, while US\$29.1 billion left the country under the radar (Kar \& Spanjers 2014; Times Live 2015). This is approximately 7.6 percent of the GDP, nearly twice the average for developing countries.

The Organization for Economic Co-operation and Development (OECD) has been on the forefront of fighting the problem of BEPS. OECD has introduced the BEPS action plan, whereby members and non-members who are willing to partake in the action plan are willing to abide by a 15-point program of implementing measures to fight BEPS. More than 100 countries have come forward to collaborate and implement the BEPS initiatives.

\section{The Need for Digitization of Taxation:}

There has been a huge change in the global tax scenario. Innovative methods of tax management are sought by not only by tax authorities but also by tax payers. Tax authorities have realized that tax laws which were largely drafted in the $20^{\text {th }}$ century are no longer suitable for the changing business situation of the $21^{\text {st }}$ century that run on high-end technology. As a result, tax authorities also have been quick in adopting new tax strategies to secure the taxes that are due and implement various reporting requirements under initiatives such as Base Erosion and Profit Shifting (BEPS) action plans. Given these changes in global taxation, there is greater need for tax payers to keep pace with the new standards on reporting and transparency.

With digitization and e-governance gaining ground, tax regulatory authorities in most of the countries are increasingly zooming in on tax compliance and expanding their tax base. Advanced technologies and analytical tools are put to use to professionalize the tax collection and monitoring mechanism and also for the authorities to remain effective and relevant.

According to report published by PWC \& Microsoft, digital transformation can help tax administrators with the following primary areas

1. Transparency

2. Taxpayer Centric Solutions

3. Connected tax stakeholders

4. Data-driven decisions and automated processes (PWC \& Microsoft, 2017) 
Research indicates that transparency that is brought about by extremely structured and visually supported data in strategy and processes can hugely increase the satisfaction of taxpayer and nudge for voluntary compliance. Further, country by country reporting as per the BEPS initiatives would encourage sharing data internationally and locally (PWC \& Microsoft, 2017).

More countries are gradually adopting the co-operative compliance models and in engaging taxpayers in revenue management. Countries are increasingly relying on analytical tools and shifting from the traditional methods to risk based co-operative compliance. As of mid-2017, 32 tax administrations had changed from traditional methods of audit to risk based co-operative compliance that heavily depends on analytics (PWC \& Microsoft, 2017). OECD cites UK's HM Revenue and Customs (HMRC) to be one of the leading examples in this regard. Since its introduction in 2006, it has achieved improvement in risk management, reduction in costs and hugely improved tax payer satisfaction (OECD). Even smaller countries like Croatia have aligned their tax administration more towards EU tax structure $\&$ administration in order to be more effective (Jerković, 2018)

Tax gap remains a big problem for most countries. Due to illicit financial flows, developing countries lose around US\$ 1 trillion a year. In developing countries there is growing need to bring more tax payers into the taxation ambit by registration, reduce tax evasion and arrest the flight of capital. It becomes even more important in these economies to embrace digitization of taxation. Even for nations with proper database of citizenry, the current mode of tax payment is a redundant system as is established by a study conducted in Nigeria (Ernest et al, 2015). According to the Internal Revenue Services (IRS) of the United States, there is a loss of around $\$ 458$ billion in a year due to illicit cash outflows. These kind of tax gaps can be clubbed only by greater engagement of taxpayers, deeper and better understanding of citizens, bringing them to voluntary declare their income and pay taxes, making tax paying work online and online interactions that will give 360degree view of the tax payers and customizing e-services and communication (Global Financial Integrity).

Digitization also helps securely exchange information and connect with other stakeholders like financial institutions, employers, stock exchange committee, insurance, chamber of commerce and more.

Tax payers expect timely, accurate and reliable services and also would like their data to be secured, ensuring high level of privacy, security and protection. Tax authorities also look to ways of efficiently collecting, securing and analyzing data. 


\section{The Journey of Tax Digitization:}

Tax Authorities around the world have been busy over the last decade with a process called "Channel Shift". This entails doing away with face to face interaction / postal contact to channels that are digitized. Though the larger picture is to digitize compliance, cost cutting is also on the agenda (ICAEW, 2016).

To optimize the benefits of digital transformation, tax authorities need to be clear about the path they need to take to achieve the transformation. The actions that they need to take may be summarized as follows.

Design a clear vision and strategic focus for the future: this is about designing and implementing a sustainable tax infrastructure, within the ambit of which will fall everything else. Most tax jurisdictions concentrate on tax legislation, double taxation treaties, transfer pricing and other technical issues. While these are fine, the jurisdictions will only end up struggling to reach the desired goals. Designing a clear focus and strategy are of paramount importance (PWC \& Microsoft, 2017).

Modernization also requires investment in change management capabilities. Digitization would be meaningless unless behavior of the people is changed to embrace the changes and let go of the old methods. This is easier said than done. One of the trends in achieving this is in co-operative compliance, an environment in which tax authorities help taxpayers understand their business. This involves employing a professional riskoriented tax auditor working with real-time compliance data.

Engage less resources to do more. This is about handling ever growing data with right digitization and set of professionals who are able to handle volumes of increasing data, analyzing and securing it. This will not only help the administration in effectively managing tax administration but also in effectively collecting taxes, making the country investor friendly and attractive to overseas investors and establishing itself as easy to do business with (PWC \& Microsoft, 2017).

A successful digital transformation would require the following components to be incorporated:

(a) Compliance strategy that involves development of compliance methodologies, re-organizing taxpayer segments such as large businesses, SMEs and individuals. Digital transformation requires compliance management. This includes the development of compliance methodologies and the reorganization of units around key taxpayer segments such as large businesses, subject matter experts (SMEs) and individuals. Management also requires a vision about tax fraud prevention and detection.

(b) Legislative framework: digitization may require new laws and rules. 
(c) Operational framework: a blue print on the core processes and compliance procedures of the tax administration. An operational framework presents a blueprint for a tax administration's core processes and compliance procedures.

(d) Tax technology and infrastructure: this involves introduction of state of the art technology to achieve the goals.

(e) Change management, training and education:

(f) Performance measurement (PWC \& Microsoft, 2017)

There is need to achieve more with less i.e. smaller budgets and fewer people. There is need to remove human interaction and achieve more by engaging analytics to drive decision making, gleam over ever increasing volumes of data and pick out what is required. The need is to be closer to the transaction than to the past data, pin point at serious tax evasion / avoidance and collect taxes more quickly (Ernst \& Young, 2017).

\section{The direction as a result of digitization:}

Most governments have the same goals. Yet, as implementation is at national level, there are many differences that need to be ironed out. No two data submissions are likely to be the same in scope. While one country may require $X$ number of fields, another country may require $X+10$ fields of data in its electronic auditing program. One country may require data to be submitted quarterly while another may require on a monthly basis and the third may require the data on demand.

Tax authorities are collecting more data that is valuable and creating a global web of tax payers.

Tax authorities are moving away from the historical data concept to closer to transaction concept. UK digital reforms require quarterly submissions followed by year end reconciliation. A similar approach is being implemented in many Latin American countries.

After moving to real time or near real time data submissions, tax authorities are moving to rapidly "layer" new data submission requirements upon one another. Latin American countries have adopted a "layering" approach, splitting tax and accounting data into "slices," each with its own submission schedule, scope and format. In the last five or six years, Brazil has rapidly increased the regular data submissions that a company must make. Now, a company must comply with 29 submission requirements, many of them monthly (Ernst \& Young, 2017).

Tax authorities are adopting data analytics to gleam over the data collected and doing away with human intervention. Though tax authorities have been using data analytics for more than 25 years, much of this was restricted to case selection. However, with the availability of advanced 
analytics with its ability to exercise data or content using sophisticated approaches such as pattern recognition, outlier detection, cluster analysis, experimental design, network analysis and text mining, new opportunities are arising to use the intelligence across all aspects of tax administration (www.oecd.org / publications / advanced analytics for better tax administration).

Most tax authorities starting their journey with VAT because it is highly transactional data. Authorities choose VAT as "Tip of the Spear".

There is increased collaboration among tax authorities as a result of monitoring and co-ordination by OECD.

There are many countries, especially in the third world, that leap frog into digitization. These countries replicate the successes demonstrated by other countries in the area and leapfrog from one level of digital maturity to another, without waiting for trial \& error method of progression. Hence, digitization is not necessarily linear or sequential (Ernst \& Young, 2017).

Many economies in the world seem to be having differences than similarities in implementing $\mathrm{CbC}$ reporting. However, a closer look highlights greater consistency than is apparent at the first look.

While layering approach is adopted by Latin American countries, European countries are adopting SAF-T (Standard Audit File for Tax) submission requirement. This approach is considered as consistent approach to tax audit and is created by OECD. Yet, a third set of countries are adopting on-demand submission approach (Ernst \& Young, 2017).

Despite the standards and co-ordination done by OECD, World Bank, IMF, United Nations and G20, tax remains sovereign business at heart. The country is responsible for introducing and implementing changes. The country level tax authority may take some of the recommendations, discard some, add some of their own and bring out legislations and changes that are apt for local conditions and businesses. That is why we find differences in submission requirements and analysis country by country (Ernst \& Young, 2015).

\section{Collective Efforts by World Organizations:}

The OECD and G20 (Group of 20) countries have developed an Inclusive Framework on BEPS, whereby countries co-operate with one another in bringing tax payers to comply with the tax requirements and pay taxes that otherwise would be missed out due to BEPS. OECD and G20 have brought out a BEPS package, a 15- point action program that will equip the participating countries to tackle BEPS more effectively (www.oecd.org/tax/beps/beps-action).

The BEPS package would equip governments with the domestic and international instruments needed to tackle BEPS. With this package, countries now have the tools to ensure that profits are taxed where economic activities 
takes place and where value is created. These tools also provide businesses greater focus and certainty by reducing disputes over the application of international tax rules and standardizing compliance requirements.

Beginning November, 2019 there were 130 jurisdictions that have signed up for the BEPS initiatives and are working closely with OECD in implementing the Inclusive Framework. The initiatives also include guidance for Country by Country $(\mathrm{CbC})$ reporting by multinationals, whereby a Tax Authority can easily get a bird's eye view of a MNC's global operations and tax liabilities (www.oecd.org/tax/beps).

International organizations acting as observers will allow more coordinated and focused capacity building in implementation of BEPS action plan.

The IMF, OECD, UN and World Bank Group (WBG) announced in April 2016 the details of their joint effort to intensify their co-operation on tax matters, with the initiation of the "Platform for Collaboration on Tax". This will facilitate regular discussions between the four organizations on the design and implementation of standards for international tax matters.

\section{Initiatives by countries:}

1. In the UK, Her Majesty's Revenue and Customs (HMRC) will be implementing Make Tax Digital (MTD) for Value Added Tax from $1^{\text {st }}$ of April, 2019. The UK has been a leader in the field of digitization with all corporate tax returns and more than $90 \%$ of personal tax returns e-filed.

2. Malaysia will be using analytics in the tax audit requirements in 2019

3. E-invoicing and e-accounting requirements will be added by Colombia in 2019

4. Ireland will be introducing real-time payroll tax reporting requirement in 2019

5. Hungary will be using live invoicing feeds for audits and assessments in 2019

6. Russia plans to introduce $\mathrm{CbC}$ reporting

7. Mexico will be increasing the use of e-assessments

8. Australia has implemented mandatory reporting of 'Single Touch Payroll' from 1.7.2018

9. Brazil has rolled out of e-invoicing to arrest the evasion of VAT. Brazil suffers from high level of fraud and corruption (Transparency International Index 38, with 0 being most corrupt and 100 being most honest). Untaxed grey economy is estimated to be $39 \%$ (ICAEW, 2016).

10. Japan planning to use analytics and Artificial Intelligence in tax administration over the next 10 years 
11. Germany having talks with Belgium and Hungary about adopting of SAF-T requirements

\section{Beyond 2020:}

Make Tax Digital (MTD) planned for other taxes by UK's HMRC

New Zealand focusing on technology policy, processes and training people

Norway will make SAF-T requirement mandatory from 1.1.2020

The above data is as of 1.1.2018 and is not exhaustive.

\section{Digitization of Taxation in India:}

India is not far behind when it comes to illicit flight of capital and lost revenue due to tax evasion / avoidance.

Table 1: Standing of India in Global \& South Asian Illicit Cash Flows:

\begin{tabular}{|l|l|l|l|}
\hline Country & $\begin{array}{l}\text { South Asian } \\
\text { Ranking }\end{array}$ & $\begin{array}{l}\text { Global } \\
\text { Ranking }\end{array}$ & $\begin{array}{l}\text { Illicit cash flows 2004- } \\
\mathbf{2 0 1 3} \text { (US\$ billion) }\end{array}$ \\
\hline India & 1 & 4 & 510.3 \\
\hline Bangladesh & 2 & 26 & 55.9 \\
\hline Sri Lanka & 3 & 53 & 19.9 \\
\hline Nepal & 4 & 86 & 5.67 \\
\hline Pakistan & 5 & 109 & 1.9 \\
\hline Afghanistan & 6 & 115 & 1.3 \\
\hline Maldives & 7 & 120 & 1.1 \\
\hline Bhutan & 8 & 132 & 0.3 \\
\hline
\end{tabular}

Source: Global Financial Integrity

It is seen from the above table that a total of US\$ 510.3 billion cash is estimated to have left the country between 2004 and 2013, making India the first in South Asia and $4^{\text {th }}$ in the world.

Table 2: Illicit Financial Outflow from India (billion US \$)

\begin{tabular}{|l|r|r|r|r|r|r|r|r|r|r|r|}
\hline & 2004 & 2005 & 2006 & 2007 & 2008 & 2009 & 2010 & 2011 & 2012 & 2013 & Total \\
\hline India & 19.5 & 20.2 & 27.8 & 34.5 & 47.2 & 29.3 & 70.3 & 85.6 & 92.9 & 83.0 & $\mathbf{5 1 0 . 3}$ \\
\hline $\begin{array}{l}\text { Developing } \\
\text { Countries }\end{array}$ & 465 & 525 & 543 & 699 & 828 & 747 & 906 & 1007 & 1035 & 1090 & $\mathbf{7 8 4 5}$ \\
\hline$\%$ & 4.2 & 3.8 & 5.1 & 4.9 & 5.7 & 3.9 & 7.8 & 8.5 & 8.9 & 7.6 & $\mathbf{6 . 5}$ \\
\hline
\end{tabular}

Illegal Finance Flows from India surged 90\% since 2007 to US\$ 62.9 billion in 2015. This was 3.01 percent of GDP in 2015.

India's journey to automate tax administration has been long. The Tax Administration Reform Commission (TARC) which was established 2013 and headed by Dr. P. Shome has given its first set of recommendations which comprise 385 recommendations towards direct taxes and 210 
recommendations towards customs and excise. The committee has recommended extensive use of technology in facilitating and easing the interaction of authorities with tax payers and improving compliance. It also recommends that technology be used in forecasting revenue. The Central Board of Direct Taxes (CBDT) and Central Board of Excise and Customs (CBEC) have been the early adopters of technology. India's journey towards tax digitization started in 1982 when it set up a separate department within the Directorate of Income Tax (Organization \& Management Services) to oversee the digitization. Other highlights are as follows:

2002: Processing of returns was computerized throughout the country. The website www.incometaxindia.gov.in) was launched to provide interface between the administration and taxpayers.

2006: Electronic filing (e-filing) of returns was launched.

2007: Integrated Taxpayer Data Management System (ITDMS) for drawing of $360^{\circ}$ taxpayer profile was launched.

2009: Setting up of Centralized Processing Centre (CPC) for bulk processing of e-filed and paper returns.

2011: Foreign Tax Division of CBDT was strengthened to effectively handle the increase in tax information exchange and transfer pricing issues.

2012: TRACES (TDS Reconciliation, Accounting and Correction Enabling System) launched to serve an integrated one-stop platform for the stakeholders to facilitate the services related to TDS operations.

2014: Enhanced new features of the website www.incometaxindia.gov.

The Government of India has also introduced RAPID (revenue, accountability, probity, information and digitalization) to narrow the gap between tax forecast and actual collection and also to achieve more userfriendly and transparent system which will eventually lead to widening of the tax base.

There has been an upswing in the tax collection since the digitization of taxation after 2000 . 
Figure 1:

\section{COLLECTION OF DIRECT TAXES IN INDIA (\$ BN)}

140.00

120.00

100.00

80.00

60.00

40.00

20.00

0.00

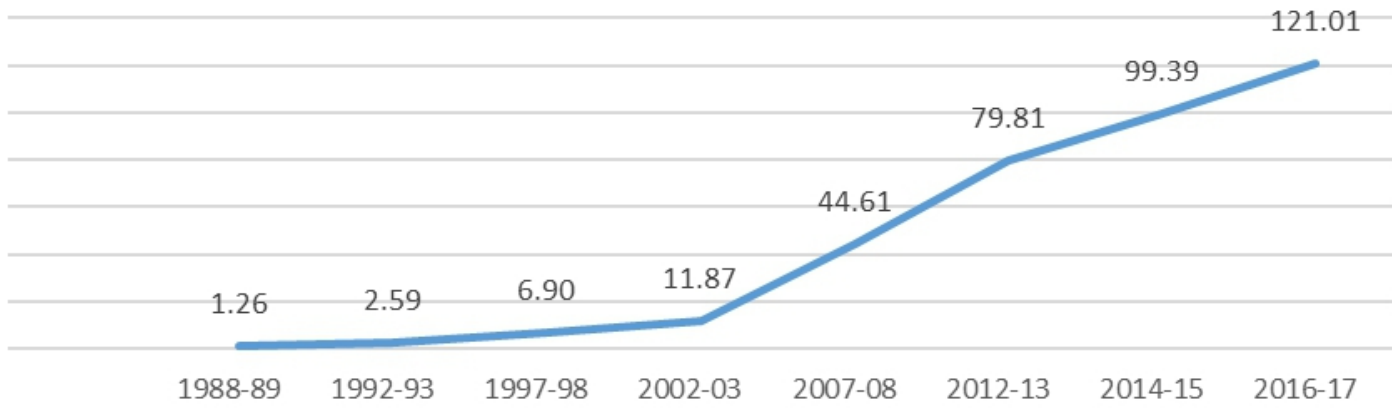

Source: Reserve Bank of India

Figure 2:

INDIA - \% OF DIRECT TAXES TO GDP

10.00
8.00
6.00
4.00
2.00
0.00

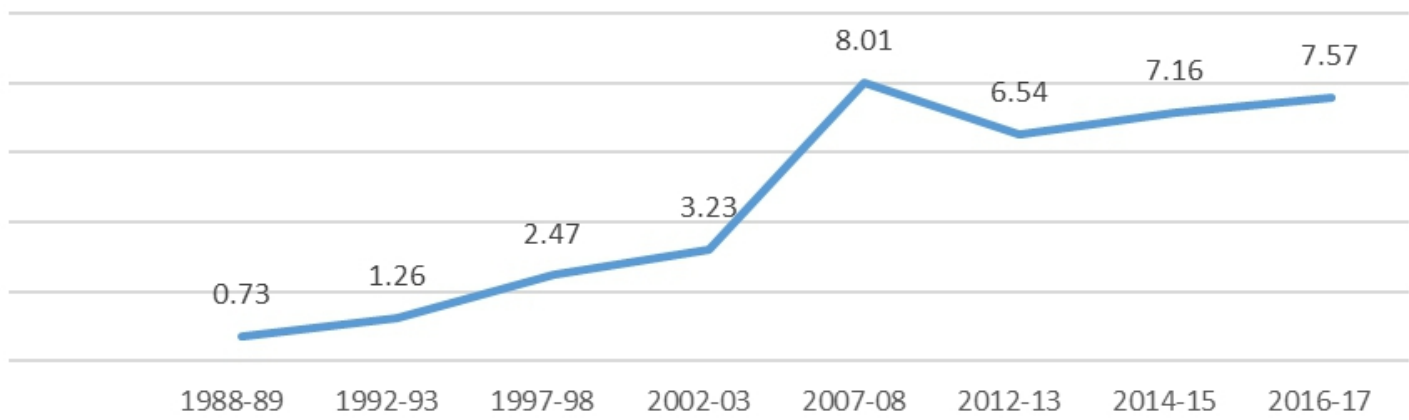

Note: GDP at constant prices calculated on base prices of 2004-05 and 2011-12

Source: Reserve Bank of India

The Government of India plans to introduce a Pan-India "Faceless and Nameless" E-Audit procedure for Income Tax payers. A high level ninemember committee has been constituted by the CBDT (The Central Board of Direct Taxes, the apex Indian policy making body for the Income Tax) to recommend modalities towards this move. The CBDT has been through pilot projects, testing the feasibility of this innovative move. As per the new system, tax assessing officers will be nominated electronically and will be location agnostic. This helps in reducing the visits of tax payers to the income tax department and their interaction with assessing officers. This will also increase the governance levels. This move is a part of the overall vision of Digital India. The Government of India has already implemented the GST Network (stateof-art IT platform for GST compliance and invoice level matching) and Project 
Insight (integrated Data warehousing \& Business Intelligence platform with advanced data analytics).

Action 13 of the BEPS Action Plan outlined by OECD provides a template for multinational enterprises (MNEs) to report annually to each tax jurisdiction they operate in, certain information contained in the template. This report is called the Country-by-Country $(\mathrm{CbC})$ Report. To report the $\mathrm{CbC}$ reporting, the BEPS action 13 includes a package consisting of (i) model legislation and (ii) three model Competent Authority Agreements that could be used to facilitate implementation of the exchange of $\mathrm{CbC}$ Reports, respectively based on the:

- Multilateral Convention on Administrative Assistance in Tax Matters;

- Bilateral tax conventions; and

- Tax Information Exchange Agreements (TIEAs)

OECD has opined that India is on the right path of achieving $\mathrm{CbC}$ reporting, except for certain changes and corrections that are needed (Peer Review Report, 2018-www.oecd.org).

\section{Conclusion}

It is very clear that tax administration model of earlier years is fading away and today the tax payer needs to provide accurate, quality checked data on demand. With the increased demand on Tax Administrations to perform within the country as well as co-operate as per the OECD guidelines, in some cases tax authorities may outpace businesses in digitization and implementation. There is increased use of data analytics and artificial intelligence in tax administrations and some tax authorities are even looking at direct access into the ERP of businesses.

The OECD has taken important measures in tackling the menace of BEPS and has laid down clear guidelines to member countries. Many advanced and developing countries including India have made important strides in digitization of tax administration and in implementing BEPS guidelines.

Digitization of taxation is for real and is already in. Taxpayers, especially business houses need to be prepared and ready at all times. Coordination with Tax Authorities is good but it is only one aspect. Going forward, collaboration with developers of new technology, taxpayers using it and tax authorities will become important.

\section{References:}

1. Cobham, A. \& Jansky, P. (2015). Measuring Misalignment: The location of US Multinationals' Economic Activity Versus the Location of their Profits. Working paper 42. International Centre for Tax \& 
Development. https://www.ictd.ac/publication

2. Ernest, E., Ogheneovo, F. \& Ayodeji, J. (2015). Design and Development of an E-Taxation System. European Scientific Journal, vol.11, pp 53-77.

3. EY Tax Insights (2017). Tax Administration Goes Digittal-2. https://taxinsights.ey.com

4. Gashi, J. (2015). Promoting Economic Growth: The Right Tax Policy for Albania. European Scientific Journal, vol.11, No. 25, pp 107-114.

5. Global Financial Integrity. http://www.gfintegrity.org

6. Government of India, Ministry of Statistics and Program Implementation, Statistical year book 2017-Direct \& Indirect Taxes. http://www.mospi.gov.in/statistical-year-book-india/2017/175.

7. Institute of Chartered Accountants of England \& Wales (ICAEW) (2016). Digitization of Tax - International Perspectives. Working paper of Information Technology Faculty, ICAEW. https://www.icaew.com

8. Irish $\mathrm{M}(2018)$. What's next for tax? Understanding the trends on the path towards digitization. Thomson Reuters working paper. https://tax.thomsonreuters.com/en/onesource.

9. Jerković E(2018). Decentralization of Financing of Self-Government Units in the Republic of Croatia. European Scientific Journal. Special edition. pp 105-118

10. Lu \& Li (2018). Government Inspectors' Penalties and Customer Loyalty of Investment: Empirical Research based on Data of Chinese Public Companies, European Scientific Journal, Vol.14. pp 21-31

11. Oguttu A.W. (2016). Tax Base Erosion and Profit Shifting in AfricaPart 1. Africa's Response to the OECD BEPS Action Plan - ICDC working paper No. 54. https://www.ictd.ac/publication/tax-baseerosion-and-profit-shifting-in-africa-part-1-africa-s-response-to-theoecd-beps-action-plan/

12. OECD publication (2016). Advanced analytics for better tax administration. www.oecd.org.

13. Organization for Economic Co-operation and Development. http://www. oecd.org.

14. Price Water Coopers and Microsoft (2017) Digital Transformation of Taxation. https://www.pwc.nl/en/publicaties/tax-administration-bypwc-and-microsoft/digital-transformation-of-tax-administration.html

15. Price Water Coopers (2017): Tax Technology - The Next Wave in Business Transformation. 1-36. https://www.pwc.in/publications/2017/tax-technology-the-next-wavein-business-transformation.html

16. Reserve Bank of India. www.rbi.org 
17. Wolfgang S. (2017). Ten Questions about Why and How to Tax the Digitalized Economy.

18. Working paper No. 11. Max Planck Institute for Tax Law and Public Finance.

19. Zhu N., Mbroh N., Monney A., Bonsu A (2019). Corporate Tax Avoidance and Firm Profitability. European Scientific Journal Vol.15, No. 7. pp 61-70 